\title{
Building a Template for Intuitive Virtual E-Commerce Shopping Site in India
}

\author{
Megharani T. Patil \\ Thadomal Shahani Engineering College/ Information Technology Department, Mumbai, 40050, India \\ E-mail: megharanitpatil@gmail.com \\ Dr. Madhuri Y. Rao \\ Thadomal Shahani Engineering College/ Information Technology Department, Mumbai, 40050, India \\ E-mail: my_rao@yahoo.com
}

Received: 25 October 2017; Accepted: 17 November 2017; Published: 08 February 2018

\begin{abstract}
With the aim to take forward the digital India mission, it is essential to building a template for intuitive e-commerce shopping site so that users can shop easily, without taking any special training. We have achieved this using several steps. First, we have documented mental model and behavioral patterns of end users while they were interacting with the shopping site. We have mapped existing shopping sites with the mental model, behavioral pattern and as a result, problem themes are identified. Effective procedures are identified to make GUI for the e-commerce shopping sites more intuitive. Based on these procedures, the prototype is designed and validated. Finally, the template for intuitive e-commerce shopping site is formed.
\end{abstract}

Index Terms-Behavioral pattern, Intuitive, Mental Model, Procedures, Prototype, Template, Virtual ecommerce shopping site.

\section{INTRODUCTION}

According to the existing recent survey, computer literacy in India is just $6.5 \%$. We still have less than $10 \%$ Internet acceptance. $70 \%$ of the country's population lives in rural areas. So, there is a need to design intuitive E-commerce shopping site which will understand user's mental model and make online shopping effortless. The design of e-commerce websites must be user-centric. If a site is difficult to understand, potential customers visit the website and leaves. To maximize the sales from online trades, companies must have simple and user-friendly ecommerce websites, which gives customers a good product perception, real and convenient shopping experience along with good customer service [1]. With the aim to take forward the digital India mission, it is essential to building the template for intuitive virtual ecommerce shopping websites so that users can do shopping easily, without any need for special training. The design of e-commerce website must be user-centric. If the design of the e-commerce website the is complicated and enigmatic, then the user will be forced to leave the website. Hence, It is crucial to ensure that they stay, and shop at the website conveniently, hence it is necessary to design the intuitive graphical user interface. To maximize revenue from online trade, companies must have a usable e-commerce website, which gives customers a good product perception, real and convenient shopping experience and good customer service. The intuitive design of GUI provides high conversion rate in e-commerce which increases sales, decreases user errors and customer support costs, reduces the cost of providing training, and finally increases user productivity. The ease with which any user can learn to operate, prepare inputs for, and interpret outputs of a system is a measure of the intuitive graphical user interface. It is only possible by collecting customer requirements and analyzing user experiences through an interview, a survey and benchmarking to form decent procedures that will deliver the intuitive design of GUI for e-commerce websites very efficiently. Key area required for it is human-computer interaction. Human-computer interaction researches the design and the use of computer technology for the interface between users and computers. HCI is situated at the intersection of design and behavior science. Design for HCI means ensuring system functionality and usability, providing effective user interaction support and enhancing a pleasant user experience through elicit feedback from users about their experiences with prototyped designs. Refine the design, based on the suggested changes. Repeat this iterative design procedure until the sensible, user-friendly interface is created [2]. Behavioural science is the systematic analysis and investigation of human behavior through controlled and naturalistic observation and disciplined scientific experimentation.

In academia, there is a persistent focus towards the cause of nation-building and realize that this is an opportune time to reduce the gap between emerging economies and developed economy. There is a serious gap between what is getting practiced in e-commerce and what is ideally possible. The demand for intuitively usable interactive e-commerce applications is increasing day by day. Thus, it is essential to reduce the time required for learning how to use a system and to increase 
usability for heterogeneous user groups. There is a need for understanding behavior study to make end user's life easy. A technical system is intuitively usable if the users' unconscious application of prior knowledge leads to effective interaction. This suggests that user interfaces should achieve a match between the user interface and the mental model of the user. There is a need to translate the mental models of the user into decent design guidelines so the user can easily access the e-commerce website with the high conversion rate to increase its competitiveness.

\section{RELATED WORK}

The demand for intuitively usable interactive ecommerce applications is increasing exponentially, to reduce the time required for learning how to use a system and to increase usability for heterogeneous user groups. There is a need for behavior study to make end user's life easier. A technical system is intuitively usable if the users' unconscious application of prior knowledge leads to effective interaction [3]. A cognitive computing solution for the design of e-commerce portal can be in terms of automation or augmentation. Automation of routine tasks can improve the overall performance of portal [4]. Mental models give us a deep understanding of user's motivations and thought processes along with the emotional and philosophical landscape in which they are operating. Mental models guide the design of the solution and help to make good user and business decisions by focusing towards the solution on what users actually need based on the feedback they have already given. A mental model is an affinity diagram of behaviors made from ethnographic data gathered from audience representatives. Once mental models are formed, one can use them to understand how current website supports people. Moreover, for task-based testing, people who do similar things are observed and their behavioral patterns are noted. Ultimately, we will get a website that understands and addresses their users [5].To satisfy customer needs, it is necessary to stay alert with the current technology and try to keep pace with it. Users find difficulties in using the facility when searching ecommerce sites, for example, users often do not know where to find the information, or how to specify a request although they have targets in their minds for most of the times. Currently, the user interface is usually designed based on the functionality without the cognitive touch on it. There is a lack of website design with the cognitive approach [6]. While designing an e-commerce website one should take care of aesthetics of the website, it's layout with readable and appealing visual aspects along with proper colors and typography [7]. If the site is well designed then, it is easy for a user to go down from general topics to specific content and to jump between related concepts via hyperlinks. Good navigation is fundamental to good web design in both business and informational sites users should be able to find information easily. If the navigation is not easy intuitive users will quickly go elsewhere in search of information
[8]. Usability of the system may enhance by adding intuitive security mechanism. Security in systems is an assurance to the user, gives them a right to a system's access to information by putting up authentication and control mechanisms making sure the users of these systems are the only ones that have been granted acceptable rights [9].Requirement Engineering and User Experience Design together make available the comprehended user requirements to product development team for successful implementation of usable product in all aspect [10]. Consider user experience and ease of access to accommodate as many users as possible regardless of user skills. User experience, i.e. how well a user understands, how he or she can interact on a site is related to layout, clear instructions and labeling on a website, i.e. how the interactive design of the site is made [11]. Effective Design of intuitive graphical user interfaces is possible with the help of solid design guidelines or procedures. Design guidelines, such as gestalt principles are available today that support designers in achieving usable user interfaces intuitively. On the other hand, these guidelines have disadvantages like being only suitable for specific user groups and offering only general advice for the design of user interfaces [12]. There are seven principles of user interface design considered during designing the case for HCI Design pattern. These design principles are tolerance, simplicity, visibility, affordance, consistency, structure and feedback [13]. Furthermore, thirteen principles of human perception and information processing can be utilized to create an effective display design which achieves a reduction in errors, a reduction in required training time, an increase in efficiency, and an increase in user satisfaction [14]. There are 10 principles for interaction design which are called as heuristics because they are broad rules of thumb and not specific usability guidelines [15]. Donald Norman introduced several basic user interface design principles and concepts that are considered for understanding why some designs are more usable and learnable than others [16]. There are certain universal golden rules for user interface design. The golden rules are divided into three groups: Place the users in control, reduce users' memory load, make the interface consistent [17]. Shneiderman's eight golden rules provide a convenient summary of the key principles of interface design. They are intended to be used during design but can also be applied to the evaluation of systems [18]. When the user interacts with the website to perform a task, he or she is involved in a cognitive activity, sustaining a cognitive cost to search, interpret and process information, and experiencing a sense of satisfaction. The degree of ambiguity and uncertainty he or she perceives and the needed search time determines the effort and the cognitive cost he or she has to sustain to perform his/her task [19].

This research work will focus on the intuitive design of user interface for Indian e-commerce website in order to increase on-site conversion rate. This research work is carried out in following flow: 
1. Documenting end user's mental model and behavioral pattern while interacting with e-commerce sites.

2. The mapping between GUI of existing shopping site with mental model and behavioral pattern of the end user.

3. Investigating procedures to make GUI for ecommerce shopping site more intuitive.

4. Validating prototype GUI for a virtual e-commerce project in India.

5. Creating a template to make e-commerce website more intuitive.

\section{COGNITIVE COMPUTING FRAMEWORK}

To carry out this work, a cognitive computing solution for the design of e-commerce portal is stated in terms of automation or augmentation models. Automation of routine tasks can improve the overall performance of portal. Automated systems can make selling process of product quick, accurate and consistent. Many other activities such as attracting the customers to buy a product do not lend to automation, so it is better to think in terms of augmentation [20]. The framework that results in work complexity and data complexity may consider four primary types of activity models named as Efficiency model, Expert model, Effectiveness model and Innovation model as shown in Table 1.

Using this framework, unstructured, volatile, and highvolume product-related data can be converted into structured, stable, low-volume so the customer can easily understand product specifications. As well as AD-HOC, unpredictable, judgment-based and all other tasks related to online shopping can be converted into routine, predictable, and rules-based activities. This work is based on the effective model, innovation model, and efficiency model. We have kept the implementation of an expert model for the future scope.

Table 1. Cognitive Computing Framework for design of e-commerce portal

\begin{tabular}{|l|l|}
\hline $\begin{array}{l}\text { Effectiveness Model(Augment) } \\
\text { (Support seamless integration and } \\
\text { collaboration) } \\
\text {-True Navigation } \\
\text {-Any time help } \\
\text {-Simple, clear and interactive web page }\end{array}$ & $\begin{array}{l}\text { Innovation Model (Augment) } \\
\text { (Enable creativity and ideation) } \\
\text {-Product learning } \\
\text {-Product catalog categorization }\end{array}$ \\
\hline $\begin{array}{l}\text { Efficiency Model(Automate) } \\
\text { (Provide consistent, low-cost performance) } \\
\text {-Registration \& Login } \\
\text {-Overall shopping process }\end{array}$ & $\begin{array}{l}\text { Expert Model(Automate) } \\
\text { (Leverage specialized expertise) } \\
\text {-Personalized Recommendation } \\
\text {-Review Summarization }\end{array}$ \\
\hline
\end{tabular}

\section{Documenting End User's Mentel Model(UMM)}

In order to improve website structure, navigation and interaction we have considered usability factors, viz. simplicity, readability, learnability, navigability, interactivity, supportability and acceptability. In userbased testing, we have conducted a survey of 405 participants by setting 27 questionnaires based on the above seven factors. Value of Cronbach alpha was 0.85 which is greater than 0.7 indicating survey data is reliable. Among them 318 responses were positive responses, rest were negative responses [21]. List of questionnaires is given in Table 2.

Participants' Demographic data were analyzed and they are categorized into three groups, viz. beginners, intermediates and experts and found 66 beginners, 179 intermediates, and 73 experts. This categorization is done based on their frequency of using computer and internet. Analysis of user's demographic characteristics is given in Table 3.

Survey responses are analyzed using Likert score statistical analysis using real statistics tool with statistical measures Mean (M), Standard Deviation (S.D). Average
Likert score Mean for beginners near 2, intermediates near 3 and experts near 4. These values mean that beginners have poor satisfaction, intermediates have the average satisfaction and experts have better satisfaction than beginners and intermediates. Likert score statistical analysis in terms of mean, standard deviation and variance is given in Table 10(Appendix).

Hypothesis testing T-test is applied on the Likert score of sample responses between different groups' beginners and intermediates, intermediates and experts, beginners and experts by stating null hypothesis (HO) and the alternative hypothesis (H1).

Null hypothesis $(\mathrm{H} 0)$ :

There is no significant difference between beginner's (beginners), intermediates and experts.

Alternative hypothesis (H1):

There is a significant difference between various user groups.

Table 4 shows the value of $P$ is $<0.05$. It is concluded that null hypothesis (H0) is false. Alternative hypothesis become true i.e. there is a significant difference between various user groups. 
Table 2. Questionnaires

\begin{tabular}{|c|c|c|}
\hline $\begin{array}{c}\text { Website } \\
\text { dimension }\end{array}$ & $\begin{array}{l}\text { Intuitive Parameters } \\
\text { (Factors for evaluation) }\end{array}$ & Questionnaires \\
\hline \multirow{3}{*}{$\begin{array}{l}\text { Website } \\
\text { Structure }\end{array}$} & Affordance (Simplicity) & $\begin{array}{l}\text { WSS1: The website provides easy registration \& login process [22]. } \\
\text { WSS2: I am able to complete my shopping quickly using this website [23]. }\end{array}$ \\
\hline & $\begin{array}{l}\text { Expectation } \\
\text { (Readability) }\end{array}$ & $\begin{array}{l}\text { WSR1: The website's wording is clear and easy to understand [24]. } \\
\text { WSR2: Every page of the website contains the appropriate amount of text \& graphical } \\
\text { components to fit into a page [24]. } \\
\text { WSR3: Website has a logical categorization of the content [25]. }\end{array}$ \\
\hline & Efficiency (Learnability) & $\begin{array}{l}\text { WSL1: Considering the home page of this site, I understand clearly what can be done [25]. } \\
\text { WSL2: Website provides complete information both on basic facts and on full product } \\
\text { details [26]. } \\
\text { WSL3: The contents provided by the website are easily understood [27]. }\end{array}$ \\
\hline $\begin{array}{l}\text { Website } \\
\text { Navigation }\end{array}$ & $\begin{array}{l}\text { Explorability } \\
\text { (Navigability) }\end{array}$ & $\begin{array}{l}\text { WNN1: The website provides a simple path to products [28]. } \\
\text { WNN2: I can easily remember how to reach the same page when I visit next time [26]. } \\
\text { WNN3: The home page of the website is easily accessible from any interior pages [25]. } \\
\text { WNN4: The website provides multiple search features to obtain the target information [29]. } \\
\text { WNN5: I am always able to go back easily to the pages that I had previously visited [25]. }\end{array}$ \\
\hline \multirow{3}{*}{$\begin{array}{l}\text { Website } \\
\text { Interaction }\end{array}$} & $\begin{array}{l}\text { Facilitation } \\
\text { (Interactivity) }\end{array}$ & $\begin{array}{l}\text { WII1: Website provides standard symbols to clarify wording [25]. } \\
\text { WII2: The website provides an appropriate amount of interactive features.[30] } \\
\text { WII3: The website keeps the user-oriented as they shop [29]. } \\
\text { WII4: The website provides features for interactive communication between customers and } \\
\text { the online company [30]. }\end{array}$ \\
\hline & $\begin{array}{l}\text { Responsiveness(Support } \\
\text { ability) }\end{array}$ & $\begin{array}{l}\text { WIS1: The website provides features to ask for help anytime I need [31]. } \\
\text { WIS2: The website provides clear feedback to user action [22]. } \\
\text { WIS3: The website supports for reading and learning about products [32]. } \\
\text { WIS4: The website provides proof of when the content was last updated or reviewed as } \\
\text { evidence that the website is being used [33]. } \\
\text { WIS5: The website allows for customization [22]. } \\
\text { WIS6: The website supports for personalizing or narrowing product lists [28]. }\end{array}$ \\
\hline & $\begin{array}{c}\text { Forgiveness } \\
\text { (Acceptability) }\end{array}$ & $\begin{array}{l}\text { WIA1: The website provides clear and easy to find contact information [33]. } \\
\text { WIA2: The website has a function to avoid errors [33]. } \\
\text { WIA3: Whenever I make a mistake using the system, I recover easily and quickly [23]. } \\
\text { WIA4: Error messages are clear and useful within website [23]. }\end{array}$ \\
\hline
\end{tabular}

Table 3. Analysis of user's demographic characteristics

\begin{tabular}{|c|c|c|c|c|c|}
\hline Sr. No & Characteristics & Range & Beginners & Intermediates & Experts \\
\hline \multirow{4}{*}{1.} & \multirow{4}{*}{ Age } & $18-25$ & 11 & 88 & 37 \\
\hline & & $26-35$ & 23 & 44 & 22 \\
\hline & & $36-45$ & 24 & 38 & 10 \\
\hline & & $46 \&$ above & 8 & 9 & 4 \\
\hline \multirow{4}{*}{2.} & \multirow{4}{*}{ Education } & Below XII & 11 & -- & -- \\
\hline & & XII & 25 & 63 & 1 \\
\hline & & Graduate & 20 & 78 & 42 \\
\hline & & Postgraduate \& Above & 10 & 38 & 30 \\
\hline \multirow{4}{*}{3.} & \multirow{4}{*}{$\begin{array}{l}\text { Frequency of using } \\
\text { Computer \& Internet }\end{array}$} & Daily & -- & -- & 73 \\
\hline & & Weekly & -- & 148 & -- \\
\hline & & Monthly & -- & 31 & -- \\
\hline & & Yearly & 66 & -- & -- \\
\hline \multirow{3}{*}{4.} & \multirow{3}{*}{$\begin{array}{l}\text { Frequency of using } \\
\text { shopping site }\end{array}$} & Weekly & -- & -- & 7 \\
\hline & & Monthly & -- & 52 & 45 \\
\hline & & Yearly & 66 & 127 & 21 \\
\hline \multirow{3}{*}{5.} & \multirow{3}{*}{$\begin{array}{l}\text { Name of shopping site } \\
\text { using frequently }\end{array}$} & Flipkart & 31 & 66 & 32 \\
\hline & & Amazon & 24 & 91 & 23 \\
\hline & & Snapdeal & 11 & 22 & 18 \\
\hline
\end{tabular}


Table 4.T-test Results

\begin{tabular}{|c|c|c|c|c|c|c|}
\hline Between-Group & StdErr & T-stat & Df & P-value & t-crit & Sig \\
\hline $\begin{array}{c}\text { Beginners and } \\
\text { Intermediates }\end{array}$ & 0.027 & 29.77 & 4806.9 & 0.001 & 1.96 & Yes \\
\hline $\begin{array}{c}\text { Intermediates } \\
\text { and Experts }\end{array}$ & 0.041 & 12.44 & 2391.6 & 0.001 & 1.96 & Yes \\
\hline $\begin{array}{c}\text { Beginners and } \\
\text { Experts }\end{array}$ & 0.056 & 22.13 & 1479.0 & 0.001 & 1.96 & Yes \\
\hline
\end{tabular}

A separate mental model for each of the user types is created from Likert score analysis and compared to see similarities and differences among the mental spaces of user segments which bring clarity to design. We can use a mental model to understand how current website supports people and what the problem themes are. The mental model for beginner, intermediate and expert (Summarized) are as shown in Table 6, Table 7 and Table 5. Detailed mental models are shown in Table 12, Table 13 and Table 14 (Appendix).

Table 5. Mental Model for Experts (Summarized)

\begin{tabular}{|c|c|c|}
\hline $\begin{array}{l}\text { Website } \\
\text { Structure }\end{array}$ & $\begin{array}{c}\text { Website } \\
\text { Navigation }\end{array}$ & Website Interaction \\
\hline $\begin{array}{l}\text { Simplicity } \\
\text { Agree }\end{array}$ & \multirow{3}{*}{$\begin{array}{c}\text { Navigability } \\
\text { Agree }\end{array}$} & $\begin{array}{c}\text { Interactivity } \\
\text { Neutral }\end{array}$ \\
\hline $\begin{array}{c}\text { Readability } \\
\text { Agree }\end{array}$ & & $\begin{array}{c}\text { Supportability } \\
\text { Neutral }\end{array}$ \\
\hline $\begin{array}{c}\text { Learnability } \\
\text { Agree }\end{array}$ & & $\begin{array}{l}\text { Acceptability } \\
\text { Neutral }\end{array}$ \\
\hline
\end{tabular}

Table 6. Mental Model for Beginner (Summarized)

\begin{tabular}{|c|c|c|}
\hline Website Structure & $\begin{array}{c}\text { Website } \\
\text { Navigation }\end{array}$ & Website Interaction \\
\hline $\begin{array}{l}\text { Simplicity } \\
\text { Disagree }\end{array}$ & \multirow{3}{*}{$\begin{array}{l}\text { Navigability } \\
\text { Disagree }\end{array}$} & $\begin{array}{l}\text { Interactivity } \\
\text { Disagree }\end{array}$ \\
\hline $\begin{array}{l}\text { Readability } \\
\text { Disagree }\end{array}$ & & $\begin{array}{l}\text { Supportability } \\
\text { Disagree }\end{array}$ \\
\hline $\begin{array}{l}\text { Learnability } \\
\text { Disagree }\end{array}$ & & $\begin{array}{l}\text { Acceptability } \\
\text { Disagree }\end{array}$ \\
\hline
\end{tabular}

Table 7. Mental Model for Intermediates (Summarized)

\begin{tabular}{|c|c|c|}
\hline $\begin{array}{l}\text { Website } \\
\text { Structure }\end{array}$ & Website Navigation & Website Interaction \\
\hline $\begin{array}{l}\text { Simplicity } \\
\text { Neutral }\end{array}$ & \multirow{3}{*}{$\begin{array}{l}\text { Navigability } \\
\text { Neutral }\end{array}$} & $\begin{array}{c}\text { Interactivity } \\
\text { Disagree }\end{array}$ \\
\hline $\begin{array}{l}\text { Readability } \\
\text { Neutral }\end{array}$ & & $\begin{array}{c}\text { Supportability } \\
\text { Disagree }\end{array}$ \\
\hline $\begin{array}{c}\text { Learnability } \\
\text { Agree }\end{array}$ & & $\begin{array}{l}\text { Acceptability } \\
\text { Neutral }\end{array}$ \\
\hline
\end{tabular}

\section{DOCUMENTING END USER's BEHAVIORAL PATTERN (UBP)}

Behavioral patterns are documented through task-based testing. 90 users performed 10 tasks. Their performance is noted in detail for each task which is shown in Table 15(Appendix). Usability testing is done through task analysis using intuitive metrics such as task success rate, relative efficiency and satisfaction level. Equation (1) and (2) are equations for task success rate, relative efficiency.
Task_Sucess_Rate $=\frac{\text { Number_of_tasks_completed_sucessfully }}{\text { Total_number_of_tasks_undertaken }} * 100 \%$

$$
\text { Relative_Efficiency }=\frac{\sum_{j=1}^{R} \sum_{i=1}^{N} n_{i j} t_{i j}}{\sum_{j=1}^{R} \sum_{i=1}^{N} t_{i j}} * 100 \%
$$

R: Number of users

$\mathrm{N}$ : Numer of tasks

$\mathrm{n}$ : Flag for successful completion of the task

$\mathrm{t}$ : Time required to complete the task

Satisfaction level was calculated by conducting a posttask survey on the Likert scale by taking the mean of all responses. Post Task Questionnaires are listed as follows:

Post Task Questionnaires :

Q.1 I satisfied with the ease of completing the tasks.

Q.2 I satisfied with the amount of time it took to complete the tasks.

Q.3 I satisfied with the support information (On-line help, messages, and documentation) when completing the tasks.

Q.4 I found the task was easy.

Q.5 I required fewer efforts to complete the task.

Q.6 I felt successful in accomplishing the task.

Q.7 I felt insecure, discouraged, irritated and annoyed while doing the task.

The result of task analysis by intuitive matrices for usability testing is illustrated in Table 8, Fig.1, and Fig. 2.

Table 8. Results of task analysis by intuitive matrices for usability testing

\begin{tabular}{|c|c|c|c|}
\hline Intuitive matrices & Beginners & Intermediates & Experts \\
\hline Task Success Rate & $10 \%$ & $60 \%$ & $80 \%$ \\
\hline Relative Efficiency & $7.59 \%$ & $40.75 \%$ & $85.44 \%$ \\
\hline $\begin{array}{c}\text { Satisfaction Level } \\
\text { Mean out of 5 }\end{array}$ & 2 & 3.43 & 4.38 \\
\hline
\end{tabular}

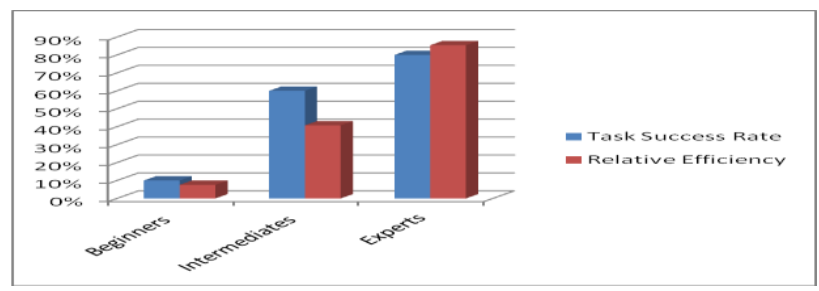

Fig.1. Graph for task analysis in terms of Task success rate \& relative efficiency (Existing Websites) 


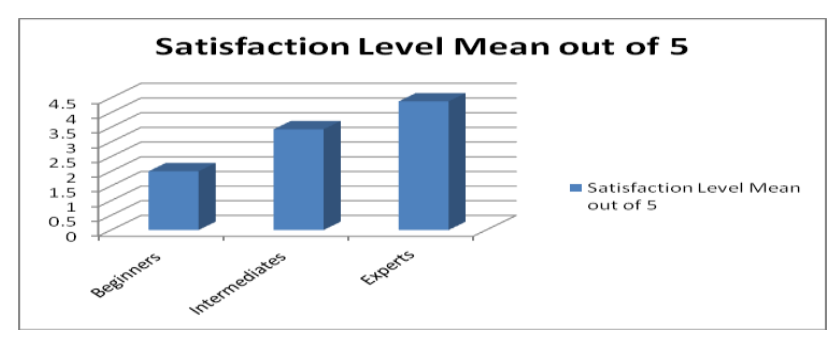

Fig.2. Graph for task analysis in terms of satisfaction level (Existing Websites)

Almost for all tasks, beginners gave up, experts performed well and intermediates were confused while performing tasks.

\section{MAPPING EXISTING GUI WITH UMM AND UBP}

Mapping of GUI with mental model and behavioral pattern of the end users is done. Gap identified in GUI of existing e-commerce shopping site are in Table 16(Appendix).

\section{Procedures to MAKe GUI INTUITIVE}

Procedures are mainly related to the website structure, the website navigation, the website interaction and their evaluation factor. The procedures to make GUI intuitive are

(i) Simplicity: Keep registration, login and whole purchase process simple so that it will be easy for the end user to understand all aspects of the website.

(ii) Readability: Website should avoid information overhead and vertical scrolling. Also, contents should be logically framed so that the user can easily read through the website.

(iii) Learnability: Website texts, contents, and information should be clear so that users can easily understand the website and decide what can be done further.

(iv) Navigability: Website should facilitate easy and rememberable movement from one web page to another web page with multiple simple and optimal paths. The home page of the website should be easily accessible from any interior pages.

(v) Interactivity: Website should provide standard symbols to clarify texts and provide interactive features and communication to enhance interactivity. Also, it should provide user orientation when they shop.

(vi) Supportability: Website should provide support to ask for help or information any time needed, clear feedback to the user action, content customization. Also, it should provide a feature for narrowing the available product list and appropriate learning about products.

(vii) Acceptability: It refers provision to avoid error, if an error occurs, there should be a clear and helpful error message. Also, it should help to recover from error to get acceptability from users.

\section{BUILDING PROTOTYPE FOR E-COMMERCE WEBSITE}

Prototyping is done with help of MockPlus prototyping tool. All pages have been designed without vertical and horizontal scrolling. More numbers of metaphors have been used to simplify website texts. Homepage design is shown in Fig. 3.

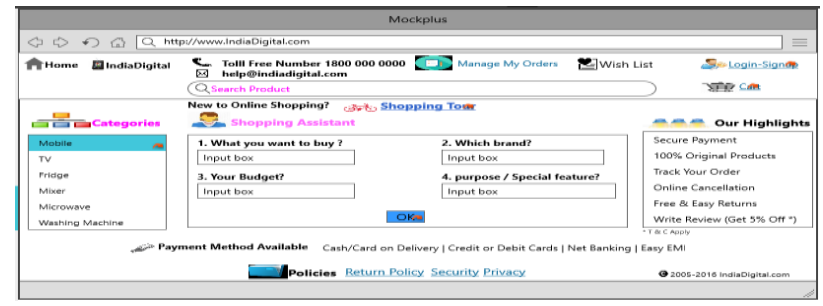

Fig.3. Home Page

Need-based filters have been introduced to personalize or customize catalog which is shown in Fig. 4. Beginners and intermediates find it difficult for attribute-based filters.

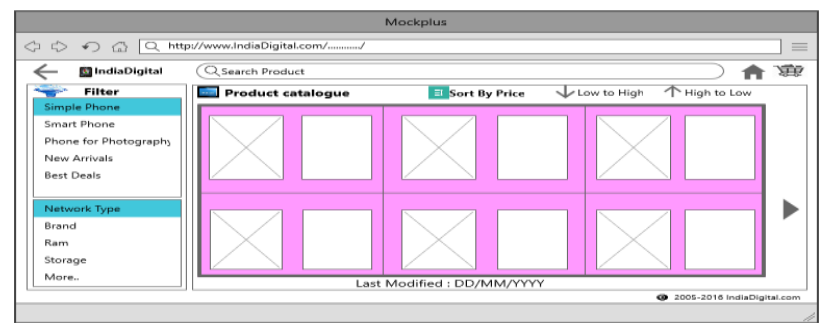

Fig.4. catalog page

To learn product in one view, tabbed windows have been used as shown in Fig. 5. In the tabbed window basic features, detailed description with videos, offers, reviews, ratings, sellers, services and all product learning related things are represented in one view so that product learning becomes easy for users.

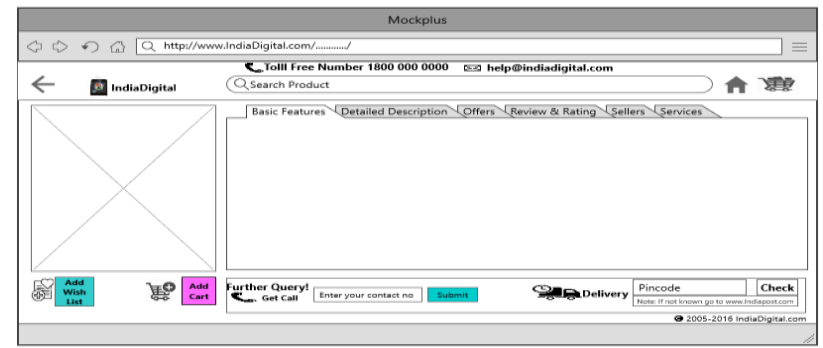

Fig.5. Product Page

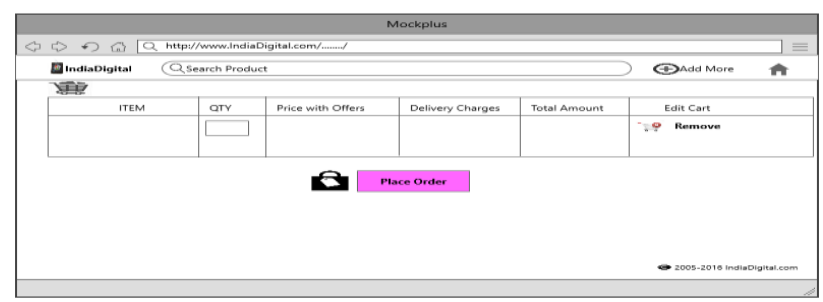

Fig.6. Cart Design 
In the shopping cart, edit cart option is highlighted which is shown in Fig. 6.

Users find it difficult to form a password and remember the password later so verification code based login and registration page has designed as shown in Fig. 7.

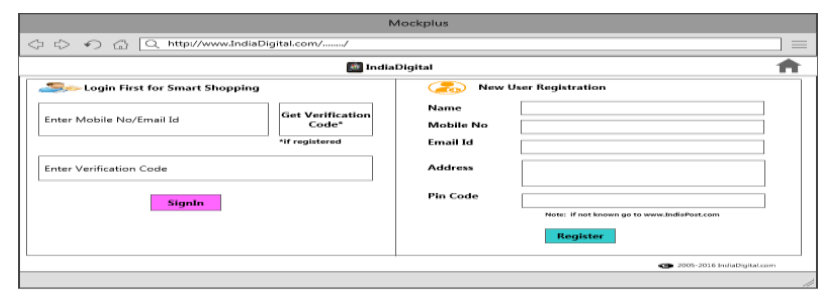

Fig.7. Login \& Registration

On the checkout page, address edit option has been provided as well as the tabbed window has been used for different payment options as shown in Fig. 8.

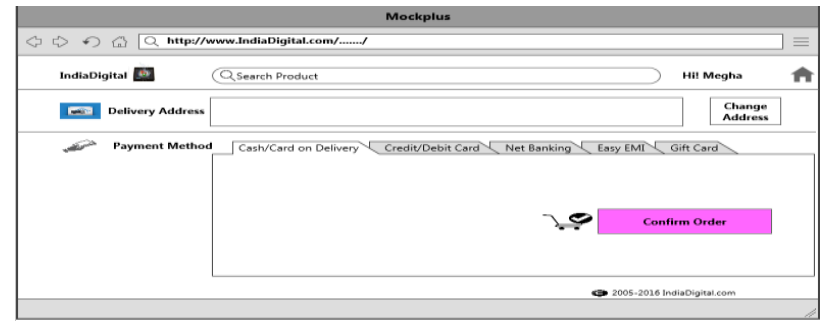

Fig.8. Checkout Process

Order acknowledgment page is kept simple with detailed order acknowledgment as well as edit options are kept for delivery address and payment method which is shown in Fig. 9.

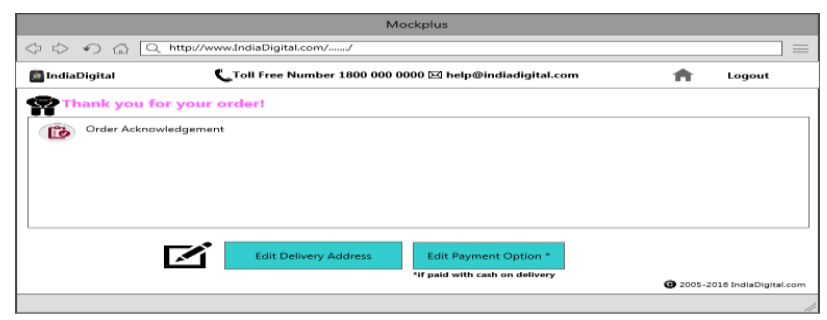

Fig.9. Order Acknowledgement

\section{VALIDAting PRototype of E-COMMERCE Website}

The prototype is validated through the test by focus groups, heuristic evaluation, guideline review through the cognitive walkthrough and usability test using thinkaloud evaluations [34].

\section{- $\quad$ Focus groups validation}

We have invited 35 expert users for this validation. They have suggested adding effective quick shopping feature for increasing conversion rate of the shopping site.

\section{- Heuristic evaluation}

We have done heuristic evaluation by 12 UX designers.
They have suggested taking care of aesthetics, typography, the positioning of various web components, and uniform size for metaphors to enhance user experience.

\section{- Guideline review through cognitive walkthrough}

This is carried out by a team of 20 web developers. Their suggestion is with regards to accommodate interactivity features such as pop-up windows or interactive video links, to add supportability features such as clear feedback to user action and acceptability feature such as a provision to avoid error, clear and useful error messages, recover from error etc.

\section{- Usability test using think-aloud evaluations}

This is done by a group of 35 beginner users who have tried to go through the purchase process. There should be the real feel of shopping with sufficient learning about the products in more visualize form.

\section{DeVeloping Template for Virtual E-COMMERCE WEBSITE}

The template is developed with the help of PHP and MySQL. All the pages have been designed without vertical and horizontal scrolling, appropriate texts, number of standard symbols, accessible home page and essential processes are highlighted. The homepage is shown in Fig. 10. In home page features like shopping tour, shopping assistant, clear page, clear and easy to find contact information, a popup window to motivate user for writing reviews and reachable true navigation such as manage my orders are added. Manage my orders page with the track, cancel, return, cancel the order and write review option is shown in Fig. 11.Shopping assistant gave a real feel of shopping. Also, reduces the number of clicks.

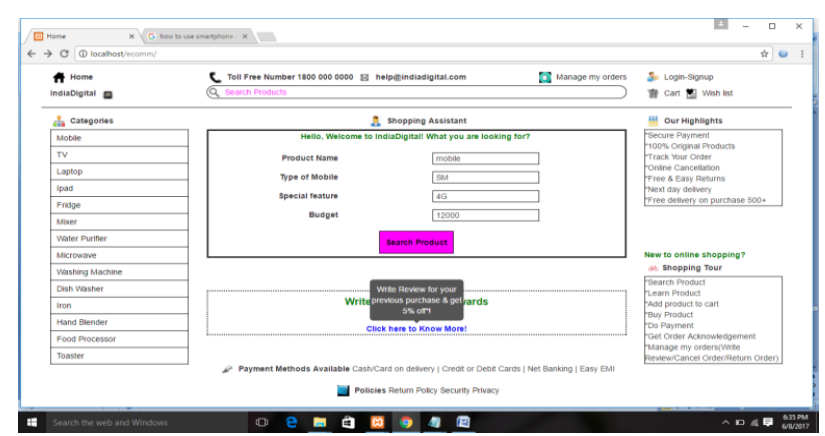

Fig.10. Home Page

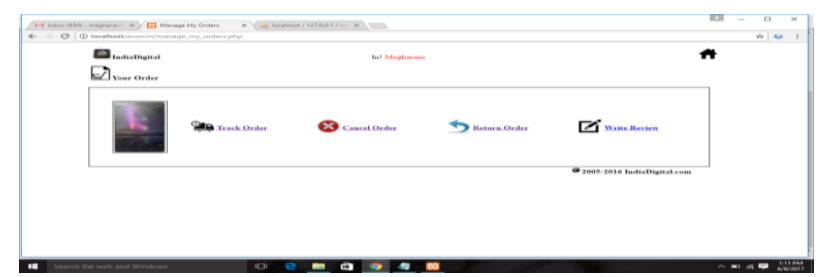

Fig.11. Manage my order page 


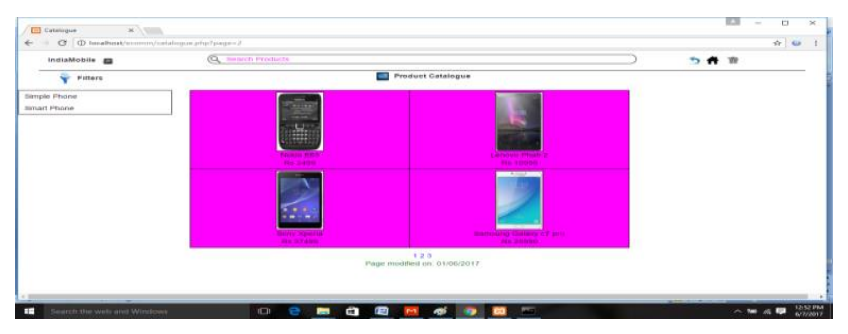

Fig.12. Product catalogue

Product catalog page is shown in Fig. 12. Features like a need-based filter, last updated date are added. In the need-based filter, two categories are added, simple phone and smartphone.

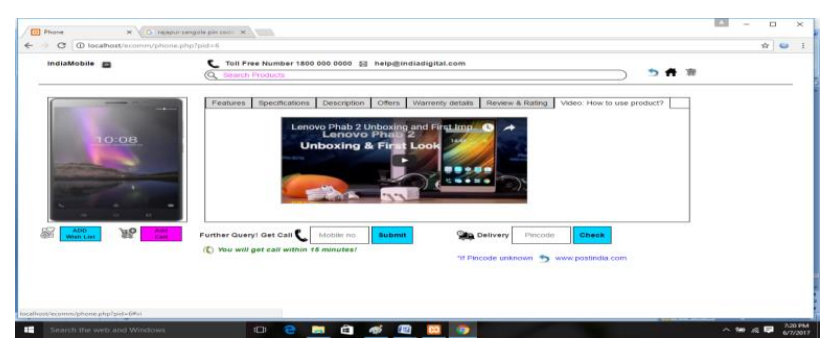

Fig.13. Product Page with clear feedback

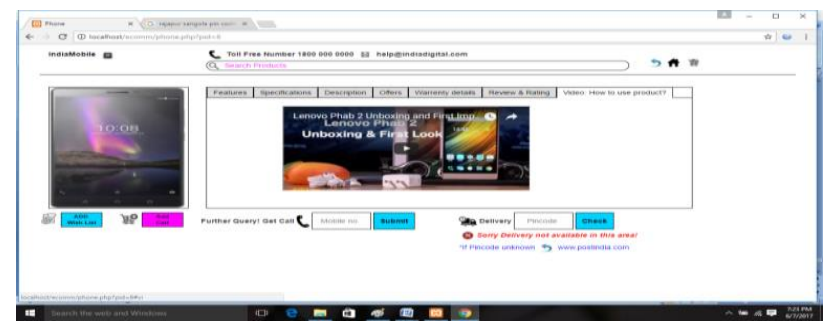

Fig.14. Product Page with clear error message

On product page, shown in Fig.13. and Fig. 14. page link to www.postindia.com is given, if anyone is unaware of the pin, to go back navigation from product page to catalogue page, direct facility to get call from online company, video link for how to use the product, clear error messages and clear feedback for user actions are added. Nav tab frame is used to avoid vertical scrolling and to enhance product learning.

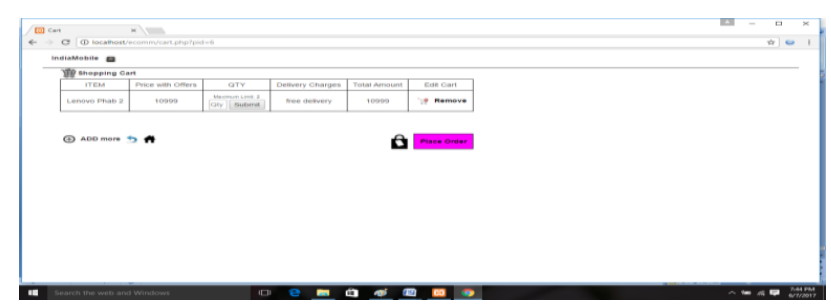

Fig.15. Cart

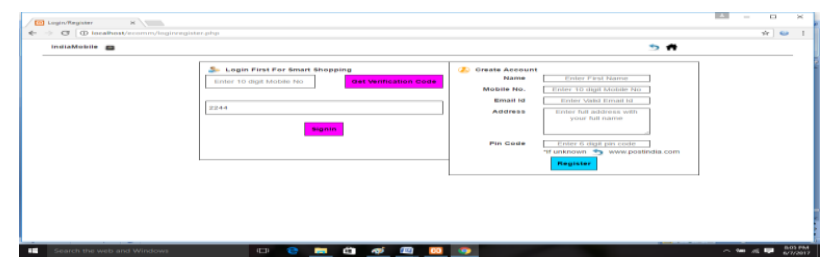

Fig.16. Login and Registration page
In cart page, as shown in Fig. 15 feature like text boxes with instructions to avoid errors, a separate column for edit cart option, true navigation are added.

Verification code based simple login \& registration process, Text boxes will give proper instructions written in a placeholder to avoid error during login and registration page which is shown in Fig. 16.

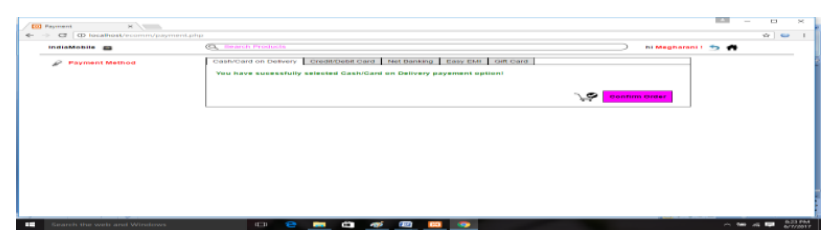

Fig.17. Payment page

Nav tab frame is used to avoid confusion while selecting appropriate payment option as shown in Fig. 17.

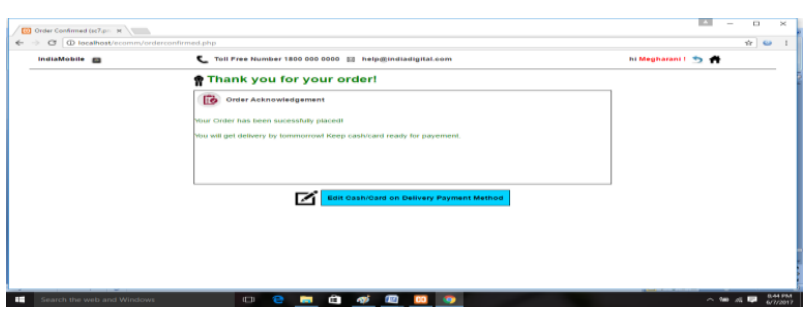

Fig.18. Order Acknowledgement

Table 9. Results of task analysis through intuitive metrics for usability testing (Virtual Website)

\begin{tabular}{|c|c|c|c|}
\hline Intuitive matrices & Beginners & Intermediates & Experts \\
\hline Task Success Rate & $70 \%$ & $90 \%$ & $100 \%$ \\
\hline $\begin{array}{c}\text { Relative } \\
\text { Efficiency }\end{array}$ & $79.80 \%$ & $96.31 \%$ & $100 \%$ \\
\hline $\begin{array}{c}\text { Satisfaction Level } \\
\text { Mean out of 5 }\end{array}$ & 3.76 & 4.38 & 4.76 \\
\hline
\end{tabular}

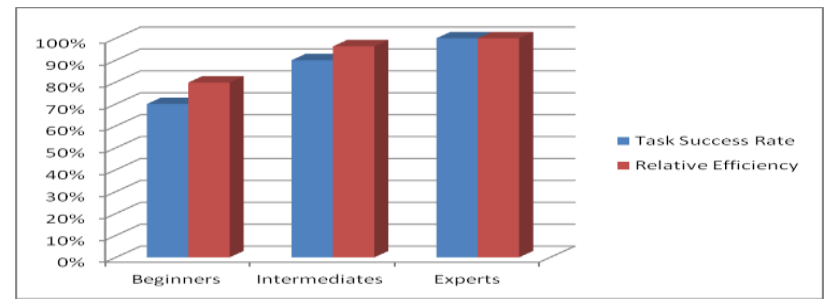

Fig.19. Graph for task analysis in terms of Task success rate \& relative efficiency (Virtual Website)

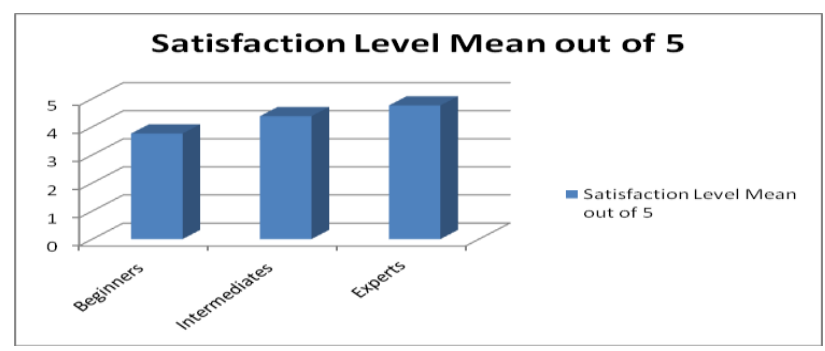

Fig.20. Graph for task analysis in terms of satisfaction level (Existing Websites)

Edit card/cash on delivery option is added in order acknowledgment page as shown in Fig. 18. 
Finally, virtual e-commerce template is tested through a survey based and task-based usability testing. The virtual e-commerce site is published. The google form link which was used for existing site's usability testing is also shared among end users for a virtual e-commerce website. 256 end users filled the survey link. Among them 212 responses were positive. Value of Cronbach alpha is 0.87 i.e greater than 7 indicating survey data is reliable. Participants' Demographic data were analyzed and categorized into three groups, viz. beginners, intermediates and experts and it were found that there are 40 beginners, 104 intermediates, and 68 experts. This categorization is done based on their frequency of using computer and internet. Survey responses are analyzed using Likert score statistical analysis using real statistics tool with statistical measures viz. mean (M), standard deviation (S.D), Cronbach alpha (C.A). Average of Likert score Mean for beginners near 4, intermediates near 4 and experts near 5. These values means, all type of personas have above average level of satisfaction. Likert score statistical analysis is in terms of mean, standard deviation and variance and is given in Table 11(Appendix). In taskbased usability testing, 90 users performed 10 tasks. Their performance is noted in detail for each task which is in Table 15(Appendix). Usability testing is done through task analysis using intuitive metrics such as task success rate, relative efficiency and satisfaction level. The result of task analysis by intuitive matrices for usability testing is illustrated in Table 9, Fig.19, and Fig. 20.

All type of personas performed tasks with at least $70 \%$ task success rate. Also, they achieved satisfaction level near 4.

\section{CONCLUSION AND FUTURE WORK}

In this paper, we extended our research which is focused towards digital India. Here, we have carried out stepwise template development for an e-commerce website. We started with documenting mental model and behavioral pattern of users that assisted us to figure out the gaps between their current knowledge and target knowledge. Based on this understanding, design procedures are formed and eventually, those are reflected in a prototype of e-commerce shopping site. The prototype is validated with standard methods. Finally, the template is formed. Implementation of expert model i.e application of artificial intelligence and machine learning is kept for future work.

\section{APPENDIX}

Table 10. Likert Score statistical analysis for existing websites

\begin{tabular}{|c|c|c|c|c|c|c|c|c|c|c|c|c|}
\hline \multirow{2}{*}{$\begin{array}{c}\text { WEBSITE } \\
\text { DIMENSION }\end{array}$} & \multirow{2}{*}{$\begin{array}{c}\text { INTUITIVE } \\
\text { PARAMETERS }\end{array}$} & \multirow{2}{*}{$\begin{array}{c}\text { EVALUATION } \\
\text { FACTOR }\end{array}$} & \multirow{2}{*}{ Q CODE } & \multicolumn{3}{|c|}{ BEGINNERS } & \multicolumn{3}{|c|}{ INTERMEDIATES } & \multicolumn{3}{|c|}{ EXPERTS } \\
\hline & & & & M. & S.D & VAR. & M. & S.D & VAR. & M. & S.D & VAR. \\
\hline \multirow{11}{*}{$\begin{array}{l}\text { Website } \\
\text { Structure }\end{array}$} & \multirow{3}{*}{ Affordance } & \multirow{3}{*}{ Simplicity } & WSS1 & 2.19 & 0.91 & 0.83 & 4.49 & 0.77 & 0.59 & 4.59 & 0.53 & 0.28 \\
\hline & & & WSS2 & 2.23 & 0.8 & 0.64 & 2.37 & 0.85 & 0.71 & 4.31 & 0.55 & 0.3 \\
\hline & & & Avg. & 2.21 & 0.86 & 0.74 & 3.43 & 0.81 & 0.65 & 4.45 & 0.54 & 0.29 \\
\hline & \multirow{4}{*}{ Expectation } & \multirow{4}{*}{ Readability } & WSR1 & 2.1 & 0.86 & 0.73 & 2.61 & 1.06 & 1.11 & 4.21 & 0.89 & 0.78 \\
\hline & & & WSR2 & 2.43 & 0.81 & 0.65 & 2.42 & 0.99 & 0.98 & 2.29 & 0.7 & 0.49 \\
\hline & & & WSR3 & 2.28 & 0.93 & 0.85 & 2.51 & 1.12 & 1.25 & 4.57 & 0.82 & 0.67 \\
\hline & & & Avg. & 2.27 & 0.87 & 0.74 & 2.51 & 1.06 & 1.12 & 3.69 & 0.80 & 0.65 \\
\hline & \multirow{4}{*}{ Efficiency } & \multirow{4}{*}{ Learnability } & WSL1 & 2.13 & 0.96 & 0.91 & 3.96 & 1.32 & 1.72 & 4.36 & 0.52 & 0.27 \\
\hline & & & WSL2 & 2.1 & 0.91 & 0.83 & 2.43 & 0.82 & 0.67 & 2.98 & 0.82 & 0.66 \\
\hline & & & WSL3 & 2.13 & 0.82 & 0.68 & 4.16 & 1.13 & 1.28 & 4.37 & 0.76 & 0.57 \\
\hline & & & Avg. & 2.12 & 0.90 & 0.81 & 3.52 & 1.09 & 1.23 & 3.90 & 0.7 & 0.5 \\
\hline \multirow{6}{*}{$\begin{array}{c}\text { Website } \\
\text { Navigation }\end{array}$} & \multirow{6}{*}{ Explorability } & \multirow{6}{*}{ Navigability } & WNN1 & 1.84 & 0.86 & 0.73 & 2.31 & 0.89 & 0.79 & 4.24 & 0.81 & 0.66 \\
\hline & & & WNN2 & 2.16 & 0.79 & 0.63 & 2.17 & 0.86 & 0.73 & 2.06 & 0.47 & 0.22 \\
\hline & & & WNN3 & 2.04 & 0.9 & 0.8 & 4.43 & 0.9 & 0.81 & 4.57 & 0.58 & 0.34 \\
\hline & & & WNN4 & 2.14 & 0.96 & 0.92 & 4.23 & 0.77 & 0.59 & 4.39 & 0.49 & 0.24 \\
\hline & & & WNN5 & 1.94 & 0.86 & 0.74 & 4.23 & 0.96 & 0.91 & 4.17 & 0.77 & 0.59 \\
\hline & & & Avg. & 2.02 & $\mathbf{0 . 8 7}$ & 0.76 & 3.47 & $\mathbf{0 . 8 8}$ & 0.77 & 3.89 & 0.62 & 0.41 \\
\hline \multirow{17}{*}{$\begin{array}{l}\text { Website } \\
\text { Interaction }\end{array}$} & \multirow{5}{*}{ Facilitation } & \multirow{5}{*}{ Interactivity } & WII1 & 2.23 & 0.93 & 0.86 & 2.14 & 0.66 & 0.43 & 2.58 & 1.34 & 1.78 \\
\hline & & & WII2 & 2 & 0.79 & 0.62 & 2.65 & 1.05 & 1.09 & 2.81 & 1.33 & 1.77 \\
\hline & & & WII3 & 2.32 & 0.9 & 0.81 & 2.37 & 1.19 & 1.42 & 3.03 & 1.43 & 1.23 \\
\hline & & & WII4 & 2.1 & 0.8 & 0.64 & 2.44 & 0.87 & 0.76 & 1.96 & 0.79 & 0.63 \\
\hline & & & Avg. & 2.16 & 0.86 & 0.73 & 2.4 & 0.94 & 0.93 & 2.60 & 1.22 & 1.35 \\
\hline & \multirow{7}{*}{ Responsiveness } & \multirow{7}{*}{ Supportability } & WIS1 & 2.02 & 0.84 & 0.7 & 2.67 & 1.35 & 1.81 & 4.65 & 0.57 & 0.32 \\
\hline & & & WIS2 & 2.11 & 0.88 & 0.78 & 2.64 & 1.07 & 1.15 & 4.35 & 0.59 & 0.34 \\
\hline & & & WIS3 & 1.97 & 0.85 & 0.71 & 2.46 & 1.03 & 1.05 & 2.1 & 0.59 & 0.34 \\
\hline & & & WIS4 & 2.16 & 0.87 & 0.75 & 2.18 & 1.03 & 1.06 & 1.77 & 0.86 & 0.74 \\
\hline & & & WIS5 & 1.99 & 0.89 & 0.79 & 2.33 & 1.14 & 1.29 & 4.44 & 0.71 & 0.5 \\
\hline & & & WIS6 & 2.08 & 0.8 & 0.63 & 2.36 & 0.95 & 0.9 & 2.11 & 0.36 & 0.13 \\
\hline & & & Avg. & 2.06 & 0.86 & 0.73 & 2.44 & 1.10 & 1.21 & 3.24 & 0.61 & 0.4 \\
\hline & \multirow{5}{*}{ Forgiveness } & \multirow{5}{*}{ Acceptability } & WIA1 & 1.88 & 0.78 & 0.61 & 2.22 & 0.89 & 0.78 & 2.8 & 1.46 & 2.14 \\
\hline & & & WIA2 & 1.9 & 0.73 & 0.53 & 2.46 & 1.06 & 1.11 & 2.81 & 1.47 & 2.16 \\
\hline & & & WIA3 & 1.97 & 0.83 & 0.68 & 4.32 & 1.04 & 1.07 & 4.28 & 0.79 & 0.62 \\
\hline & & & WIA4 & 2.1 & 0.78 & 0.61 & 2.67 & 1.13 & 1.26 & 2.77 & 1.47 & 2.16 \\
\hline & & & Avg. & 1.96 & 0.78 & 0.61 & 2.92 & 1.03 & 1.06 & 3.17 & 1.30 & 1.77 \\
\hline & Overall Evaluatio & & Avg. & 2.11 & 0.86 & 0.74 & 2.96 & 0.99 & 0.99 & 3.56 & 0.83 & 0.77 \\
\hline
\end{tabular}


Table 11. Likert Score statistical analysis for virtual e-commerce shopping site

\begin{tabular}{|c|c|c|c|c|c|c|c|c|c|c|c|c|}
\hline \multirow{2}{*}{$\begin{array}{c}\text { WEBSITE } \\
\text { DIMENSION }\end{array}$} & \multirow{2}{*}{$\begin{array}{c}\text { INTUITIVE } \\
\text { PARAMETERS }\end{array}$} & \multirow{2}{*}{$\begin{array}{l}\text { EVALUATION } \\
\text { FACTOR }\end{array}$} & \multirow{2}{*}{ Q CODE } & \multicolumn{3}{|c|}{ BEGINNERS } & \multicolumn{3}{|c|}{ INTERMEDIATES } & \multicolumn{3}{|c|}{ EXPERTS } \\
\hline & & & & M. & S.D & VAR. & M. & S.D & VAR. & M. & S.D & VAR. \\
\hline \multirow{11}{*}{$\begin{array}{l}\text { Website } \\
\text { Structure }\end{array}$} & \multirow{3}{*}{ Affordance } & \multirow{3}{*}{ Simplicity } & WSS1 & 3.7 & 0.67 & 0.46 & 3.96 & 0.66 & 0.44 & 4.47 & 0.51 & 0.26 \\
\hline & & & WSS2 & 3.9 & 0.74 & 0.54 & 3.92 & 0.84 & 0.71 & 4.81 & 0.4 & 0.16 \\
\hline & & & Avg. & 3.8 & 0.71 & 0.5 & 3.94 & 0.75 & 0.58 & 4.64 & 0.46 & 0.21 \\
\hline & \multirow{4}{*}{ Expectation } & \multirow{4}{*}{ Readability } & WSR1 & 3.9 & 0.74 & 0.54 & 4.04 & 0.53 & 0.28 & 4.71 & 0.47 & 0.22 \\
\hline & & & WSR2 & 3.9 & 0.57 & 0.32 & 4.08 & 0.56 & 0.31 & 4.65 & 0.49 & 0.24 \\
\hline & & & WSR3 & 3.6 & 0.7 & 0.49 & 4 & 0.63 & 0.4 & 4.47 & 0.62 & 0.39 \\
\hline & & & Avg. & 3.8 & 0.67 & 0.45 & 4.04 & 0.57 & 0.33 & 4.61 & 0.53 & 0.28 \\
\hline & \multirow{4}{*}{ Efficiency } & \multirow{4}{*}{ Learnability } & WSL1 & 4.2 & 0.63 & 0.4 & 3.85 & 0.73 & 0.54 & 4.41 & 0.62 & 0.38 \\
\hline & & & WSL2 & 3.8 & 0.79 & 0.62 & 3.81 & 0.85 & 0.72 & 4.75 & 0.45 & 0.2 \\
\hline & & & WSL3 & 4 & 0.67 & 0.44 & 4.12 & 0.52 & 0.27 & 4.59 & 0.51 & 0.26 \\
\hline & & & Avg. & 4 & 0.7 & 0.49 & 3.92 & 0.7 & 0.51 & 4.58 & 0.52 & 0.28 \\
\hline \multirow{6}{*}{$\begin{array}{c}\text { Website } \\
\text { Navigation }\end{array}$} & \multirow{6}{*}{ Explorability } & \multirow{6}{*}{ Navigability } & WNN1 & 4 & 0.82 & 0.67 & 3.96 & 0.45 & 0.2 & 4.65 & 0.49 & 0.24 \\
\hline & & & WNN2 & 3.7 & 0.67 & 0.46 & 4.23 & 0.43 & 0.18 & 4.65 & 0.61 & 0.37 \\
\hline & & & WNN3 & 4 & 0.47 & 0.22 & 4.08 & 0.63 & 0.39 & 4.35 & 0.61 & 0.37 \\
\hline & & & WNN4 & 3.9 & 0.32 & 0.1 & 3.96 & 0.77 & 0.6 & 4.59 & 0.51 & 0.26 \\
\hline & & & WNN5 & 3.9 & 0.57 & 0.32 & 4.04 & 0.6 & 0.36 & 4.69 & 0.6 & 0.36 \\
\hline & & & Avg. & 3.9 & 0.57 & 0.35 & 4.05 & 0.58 & 0.35 & 4.58 & 0.56 & 0.32 \\
\hline \multirow{17}{*}{$\begin{array}{c}\text { Website } \\
\text { Interaction }\end{array}$} & \multirow{5}{*}{ Facilitation } & \multirow{5}{*}{ Interactivity } & WII1 & 3.8 & 1.03 & 1.07 & 4 & 0.69 & 0.48 & 4.53 & 0.51 & 0.26 \\
\hline & & & WII2 & 4.2 & 0.42 & 0.18 & 4.15 & 0.67 & 0.46 & 4.59 & 0.51 & 0.26 \\
\hline & & & WII3 & 3.7 & 0.82 & 0.68 & 4.04 & 0.54 & 0.29 & 4.41 & 0.51 & 0.26 \\
\hline & & & WII4 & 4 & 0.47 & 0.22 & 4 & 0.4 & 0.16 & 4.65 & 0.49 & 0.24 \\
\hline & & & Avg. & 3.92 & 0.69 & 0.54 & 4.05 & 0.58 & 0.35 & 4.54 & 0.51 & 0.26 \\
\hline & \multirow{7}{*}{ Responsiveness } & \multirow{7}{*}{ Supportability } & WIS1 & 4.1 & 0.74 & 0.54 & 4.15 & 0.46 & 0.22 & 4.76 & 0.44 & 0.19 \\
\hline & & & WIS2 & 4.1 & 0.57 & 0.32 & 4.04 & 0.6 & 0.36 & 4.53 & 0.51 & 0.26 \\
\hline & & & WIS3 & 4 & 0 & 0 & 4.12 & 0.33 & 0.11 & 4.59 & 0.51 & 0.26 \\
\hline & & & WIS4 & 4 & 0.67 & 0.44 & 3.96 & 0.45 & 0.2 & 4.71 & 0.47 & 0.22 \\
\hline & & & WIS5 & 4 & 0.67 & 0.44 & 4.04 & 0.6 & 0.36 & 4.59 & 0.51 & 0.26 \\
\hline & & & WIS6 & 4 & 0 & 0 & 4 & 0.4 & 0.16 & 4.53 & 0.62 & 0.39 \\
\hline & & & Avg. & 4.03 & 0.44 & 0.29 & 4.05 & 0.47 & 0.23 & 4.62 & 0.51 & 0.26 \\
\hline & \multirow{5}{*}{ Forgiveness } & \multirow{5}{*}{ Acceptability } & WIA1 & 4 & 0.47 & 0.22 & 4.04 & 0.53 & 0.28 & 4.69 & 0.48 & 0.23 \\
\hline & & & WIA2 & 3.9 & 0.74 & 0.54 & 4.15 & 0.67 & 0.46 & 4.47 & 0.51 & 0.26 \\
\hline & & & WIA3 & 3.8 & 0.63 & 0.4 & 4 & 0.49 & 0.24 & 4.35 & 0.49 & 0.24 \\
\hline & & & WIA4 & 4 & 0.47 & 0.22 & 3.92 & 0.48 & 0.23 & 4.63 & 0.5 & 0.25 \\
\hline & & & Avg. & 3.92 & 0.58 & 0.35 & 4.03 & 0.54 & 0.3 & 4.53 & 0.5 & 0.25 \\
\hline & Overall Evaluati & & Avg. & 3.91 & 0.62 & 0.42 & 4.01 & 0.6 & 0.38 & 4.59 & 0.51 & 0.27 \\
\hline
\end{tabular}


Table 12. Mental Model for Beginner (Detailed)

\begin{tabular}{|c|c|c|}
\hline \multicolumn{3}{|c|}{ Mental model for Beginners } \\
\hline Website Structure & Website Navigation & Website User Experience \\
\hline $\begin{array}{l}\text { Simplicity } \\
\text { Disagree for website provides easy and } \\
\text { quick registration, login and purchase process. }\end{array}$ & \multirow{3}{*}{$\begin{array}{l}\text { Navigability } \\
\text { Disagree for } \\
\text { - Website provides simple path to the } \\
\text { product } \\
\text { - Can reach easily to a page in next } \\
\text { visit. } \\
\text { The home page of the website is } \\
\text { easily accessible from any interior } \\
\text { pages. } \\
\text { Provides multiple search features to } \\
\text { obtain the target information. } \\
\text { Able to go back easily to the pages } \\
\text { that I had previously visited. }\end{array}$} & $\begin{array}{l}\text { Interactivity } \\
\text { Disagree for website having standard } \\
\text { symbols to clarify wording, an appropriate } \\
\text { amount of interactive feature, and } \\
\text { interactive communication and keeping user } \\
\text { orientation as they shop. }\end{array}$ \\
\hline $\begin{array}{l}\text { Readability } \\
\text { Disagree for website texts, appropriate } \\
\text { amount of text, graphical components to fit } \\
\text { into a page and logical categorization of } \\
\text { contents }\end{array}$ & & $\begin{array}{l}\text { Supportability } \\
\text { Disagree for website provides any time } \\
\text { help feature, feedback to a user action, } \\
\text { getting support for reading and learning } \\
\text { about the products, provides proof of when } \\
\text { contents were last updated, personalization } \\
\text { and customization. }\end{array}$ \\
\hline $\begin{array}{l}\text { Learnability } \\
\text { Disagree with an understanding of home } \\
\text { page, other website contents, complete } \\
\text { information both basic facts and full product } \\
\text { details. }\end{array}$ & & $\begin{array}{l}\text { Acceptability } \\
\text { Disagree with the website have easy to } \\
\text { find contact information, function to avoid } \\
\text { errors, clarity, and usefulness of error } \\
\text { messages, easy and quick recovery of } \\
\text { mistakes made by users. }\end{array}$ \\
\hline
\end{tabular}

Table 13. Mental Model for Intermediates (Detailed)

\begin{tabular}{|c|c|c|}
\hline \multicolumn{3}{|c|}{ Mental model for Intermediates } \\
\hline Website Structure & Website Navigation & Website User Experience \\
\hline $\begin{array}{l}\text { Simplicity } \\
\text { Agree for website provides easy and } \\
\text { quick registration, login but disagree with } \\
\text { the quick purchase process. }\end{array}$ & $\begin{array}{l}\text { Navigability } \\
\text { Agree for } \\
\text { - The home page of the website is } \\
\text { easily accessible from any } \\
\text { interior pages. }\end{array}$ & $\begin{array}{l}\text { Interactivity } \\
\text { Disagree for website having standard symbols to } \\
\text { clarify wording, an appropriate amount of interactive } \\
\text { feature, and interactive communication and keeping } \\
\text { user orientation as they shop. }\end{array}$ \\
\hline $\begin{array}{l}\text { Readability } \\
\text { Disagree for website texts, an } \\
\text { appropriate amount of text, graphical } \\
\text { components to fit into a page and logical } \\
\text { categorization of contents. }\end{array}$ & $\begin{array}{l}\text { - Provides multiple search features } \\
\text { to obtain the target information. } \\
\text { - Can reach easily to a page in next } \\
\text { visit. } \\
\text { Disagree for }\end{array}$ & $\begin{array}{l}\text { Supportability } \\
\text { Disagree for website provides any time help } \\
\text { feature, feedback to a user action, getting support for } \\
\text { reading and learning about the products, provides } \\
\text { proof of when contents were last updated, } \\
\text { personalization and customization. }\end{array}$ \\
\hline $\begin{array}{l}\text { Learnability } \\
\text { Agree for an understanding of home } \\
\text { page, other website contents. Disagree for } \\
\text { provides complete information both basic } \\
\text { facts and full product details. }\end{array}$ & $\begin{array}{l}\text { - Website provides simple path to } \\
\text { the product } \\
\text { - Able to go back easily to the } \\
\text { pages that I had previously } \\
\text { visited. }\end{array}$ & $\begin{array}{l}\text { Acceptability } \\
\text { Disagree with the website have easy to find } \\
\text { contact information, function to avoid errors, clarity, } \\
\text { and usefulness of error messages. Agree for easy and } \\
\text { quick recovery of mistakes made by users. }\end{array}$ \\
\hline
\end{tabular}

Table 14. Mental Model for experts (Detailed)

\begin{tabular}{|c|c|c|}
\hline \multicolumn{3}{|c|}{ Mental model for experts } \\
\hline Website Structure & Website Navigation & Website User Experience \\
\hline $\begin{array}{l}\text { Simplicity } \\
\text { Strongly Agree for website provides } \\
\text { easy and quick registration, login. Agree } \\
\text { for quick purchase process. }\end{array}$ & $\begin{array}{l}\text { Navigability } \\
\text { Agree for } \\
\text { - Website provides simple path to } \\
\text { the product } \\
\text { - Can reach easily to a page in }\end{array}$ & $\begin{array}{l}\text { Interactivity } \\
\text { Neutral for website having standard symbols to } \\
\text { clarify wording, appropriate amount of interactive } \\
\text { feature. Disagree for provides interactive } \\
\text { communication and keeping user orientation as they } \\
\text { shop. }\end{array}$ \\
\hline $\begin{array}{l}\text { Readability } \\
\text { Agree for website texts), for logical } \\
\text { categorization of contents. Disagree for } \\
\text { the appropriate amount of text, graphical } \\
\text { components to fit into a page. }\end{array}$ & $\begin{array}{l}\text { - The home page of the website is } \\
\text { easily accessible from any } \\
\text { interior pages. } \\
\text { - Provides multiple search features } \\
\text { to obtain the target information. }\end{array}$ & $\begin{array}{l}\text { Supportability } \\
\text { Strongly Agree for website provides any time help } \\
\text { feature. Agree for providing clear feedback to user } \\
\text { action and customization. Disagree for getting support } \\
\text { for reading and learning about the products, provides } \\
\text { proof of when contents were last updated, } \\
\text { personalization }\end{array}$ \\
\hline $\begin{array}{l}\text { Learnability } \\
\text { Agree for an understanding of home } \\
\text { page, other website contents. Neutral for } \\
\text { provides complete information both } \\
\text { basic facts and full product details. }\end{array}$ & $\begin{array}{l}\text { Disagree for } \\
\text { - Able to go back easily to the } \\
\text { pages that I had previously } \\
\text { visited. }\end{array}$ & $\begin{array}{l}\text { Acceptability } \\
\text { Disagree with the website have easy to find contact } \\
\text { information, function to avoid errors, clarity, and } \\
\text { usefulness of error messages. Agree for easy and } \\
\text { quick recovery of mistakes made by users. }\end{array}$ \\
\hline
\end{tabular}


Table 15. Behavioral pattern of end users while accessing website (Existing website and Virtual Website)

\begin{tabular}{|c|c|c|c|c|}
\hline Task ID & Task & Beginners & Intermediates & Experts \\
\hline \multicolumn{5}{|c|}{ Existing Website } \\
\hline T1 & Open the website & $\begin{array}{c}\text { They searched website by typing } \\
\text { name of website in Google search } \\
\text { engine. }\end{array}$ & $\begin{array}{l}\text { They searched website by typing } \\
\text { name of website in Google search } \\
\text { engine but few of them have typed } \\
\text { URL in browser. }\end{array}$ & $\begin{array}{c}\text { They Opened the website by typing } \\
\text { URL in browser. }\end{array}$ \\
\hline T2 & $\begin{array}{l}\text { Get familiar with website and } \\
\text { search for the product. }\end{array}$ & $\begin{array}{l}\text { They were confused to read and } \\
\text { understand the website because of } \\
\text { too much of vertical scrolling. They } \\
\text { lose their patience in scrolling. } \\
\text { They were not comfortable for } \\
\text { finding relevant product page. They } \\
\text { required help. }\end{array}$ & $\begin{array}{l}\text { They were having partial } \\
\text { understanding of website so they } \\
\text { immediately clicked on } \\
\text { advertisement and moved to that } \\
\text { webpage and become confused. User } \\
\text { preferred to find product through } \\
\text { search engine. }\end{array}$ & $\begin{array}{l}\text { Users easily understand how to use } \\
\text { website. They did not clicked on } \\
\text { page immediately but browse the } \\
\text { page up and down for getting target } \\
\text { information. They managed to find } \\
\text { the relevant product through menu } \\
\text { bar comfortably. }\end{array}$ \\
\hline T3 & $\begin{array}{l}\text { Customize the product } \\
\text { catalog \& learn about } \\
\text { required product. }\end{array}$ & $\begin{array}{l}\text { They give up to find the product } \\
\text { based on one or another factor price } \\
\text { range, viewing reviews and } \\
\text { recommendations. }\end{array}$ & $\begin{array}{l}\text { They managed to find the product } \\
\text { only based on price range and give up } \\
\text { for viewing reviews and } \\
\text { recommendations. }\end{array}$ & $\begin{array}{l}\text { Users spend some time for Selecting } \\
\text { price range, viewing reviews and } \\
\text { recommendations. }\end{array}$ \\
\hline T4 & $\begin{array}{l}\text { Add product to cart, change } \\
\text { quantity, Remove product, } \\
\text { Place order. }\end{array}$ & $\begin{array}{l}\text { They require help to perform all } \\
\text { these subtask. }\end{array}$ & $\begin{array}{c}\text { When user by mistake removed } \\
\text { product from cart and want to add } \\
\text { same product again but there was no } \\
\text { option to go back to the same product } \\
\text { page and redo the action so user get } \\
\text { confused. }\end{array}$ & Users easily carried out this task. \\
\hline T5 & $\begin{array}{l}\text { Registration and login } \\
\text { process. }\end{array}$ & $\begin{array}{l}\text { Finding difficulty in forming } \\
\text { password and recall pin code. }\end{array}$ & $\begin{array}{l}\text { Users were showing irritation to } \\
\text { recollect the password and proceed } \\
\text { further for purchase process. }\end{array}$ & $\begin{array}{l}\text { Users easily performed these } \\
\text { subtasks. }\end{array}$ \\
\hline T6 & $\begin{array}{l}\text { Select payment option. } \\
\text { Payment processing and view } \\
\text { Confirmation of purchase. }\end{array}$ & $\begin{array}{l}\text { Confused to select payment options } \\
\text { and view confirmation of purchase. }\end{array}$ & $\begin{array}{l}\text { Initially users were confused where } \\
\text { to look for confirmation of purchase. }\end{array}$ & $\begin{array}{l}\text { Users easily performed these } \\
\text { subtasks. }\end{array}$ \\
\hline T7 & $\begin{array}{c}\text { Track order, Cancellation or } \\
\text { return process for placed } \\
\text { order. }\end{array}$ & $\begin{array}{l}\text { Difficulty to find cancellation and } \\
\text { return process. }\end{array}$ & $\begin{array}{l}\text { Performed cancellation and return by } \\
\text { taking help from site FAQs etc. }\end{array}$ & $\begin{array}{l}\text { Users easily performed mange order } \\
\text { tasks. }\end{array}$ \\
\hline T8 & $\begin{array}{c}\text { Edit payment option after } \\
\text { order confirmation. }\end{array}$ & $\begin{array}{l}\text { Unable to find edit payment option } \\
\text { as it is missing. }\end{array}$ & $\begin{array}{l}\text { Unable to find edit payment option as } \\
\text { it is missing. }\end{array}$ & $\begin{array}{l}\text { Unable to find edit payment option } \\
\text { as it is missing. }\end{array}$ \\
\hline T9 & Get anytime help required. & $\begin{array}{l}\text { Unable to get connected with } \\
\text { online company instantly. Unable } \\
\text { find solutions for general queries } \\
\text { through FAQs. }\end{array}$ & $\begin{array}{l}\text { Unable to get connected with online } \\
\text { company instantly. For some of } \\
\text { queries they got help from FAQs but } \\
\text { many queries were unanswered. }\end{array}$ & $\begin{array}{c}\text { Unable to get connected with online } \\
\text { company instantly. For majority of } \\
\text { queries they got help from FAQs } \\
\text { but for few queries not able to get } \\
\text { help immediately. }\end{array}$ \\
\hline T10 & $\begin{array}{l}\text { Writing review for purchased } \\
\text { product }\end{array}$ & $\begin{array}{l}\text { Not shown interest as they are } \\
\text { beginners for website. }\end{array}$ & $\begin{array}{l}\text { Difficulty to remember and go back } \\
\text { to product page for finding write } \\
\text { review option. }\end{array}$ & Users easily performed this task. \\
\hline \multicolumn{5}{|c|}{ Virtual Website } \\
\hline T1 & Open the website & $\begin{array}{l}\text { They Opened the website by typing } \\
\text { URL in the browser as per the } \\
\text { instruction was given. }\end{array}$ & $\begin{array}{l}\text { They Opened the website by typing } \\
\text { URL in the browser as per the } \\
\text { instruction was given. }\end{array}$ & $\begin{array}{l}\text { They Opened the website by typing } \\
\text { URL in the browser as per the } \\
\text { instruction was given. }\end{array}$ \\
\hline T2 & $\begin{array}{l}\text { Get familiar with the website } \\
\text { and search for the product. }\end{array}$ & $\begin{array}{l}\text { Searched product through shopping } \\
\text { assistant. Some of them tried with } \\
\text { the menu bar. }\end{array}$ & $\begin{array}{l}\text { Moved cursor towards shopping } \\
\text { assistant but finally decided to search } \\
\text { through the menu bar. }\end{array}$ & $\begin{array}{l}\text { Searched product through the menu } \\
\text { bar. }\end{array}$ \\
\hline T3 & $\begin{array}{l}\text { Customize the product } \\
\text { catalog } \& \text { learn about the } \\
\text { required product. }\end{array}$ & $\begin{array}{l}\text { Able to customize the product list } \\
\text { using a need-based filter. Also } \\
\text { learned about the product through } \\
\text { nav based tabs. Took time to learn } \\
\text { about the product. }\end{array}$ & $\begin{array}{c}\text { Customized the product list and } \\
\text { learned about the product through } \\
\text { nav based tabs by taking moderate } \\
\text { time. }\end{array}$ & $\begin{array}{l}\text { Immediately customized the product } \\
\text { list and learned about the product } \\
\text { through nav based tabs. }\end{array}$ \\
\hline T4 & $\begin{array}{l}\text { Add product to cart, change } \\
\text { the quantity, Remove } \\
\text { product, Place order. } \\
\end{array}$ & $\begin{array}{c}\text { Performed all tasks by taking more } \\
\text { time. }\end{array}$ & $\begin{array}{l}\text { Performed all tasks by taking } \\
\text { moderate time. }\end{array}$ & Immediately performed all tasks. \\
\hline T5 & $\begin{array}{c}\text { Registration and login } \\
\text { process. }\end{array}$ & $\begin{array}{l}\text { Took more time to register and } \\
\text { login. }\end{array}$ & $\begin{array}{c}\text { Registered and logged in by taking } \\
\text { moderate time. }\end{array}$ & $\begin{array}{c}\text { Immediately performed registration } \\
\text { \& login process. }\end{array}$ \\
\hline T6 & $\begin{array}{l}\text { Select payment option. } \\
\text { Payment processing and view } \\
\text { Confirmation of purchase. }\end{array}$ & $\begin{array}{l}\text { They selected payment option and } \\
\text { made themselves aware of the } \\
\text { confirmation of purchase through } \\
\text { nav based tabs. }\end{array}$ & $\begin{array}{c}\text { They selected payment option and } \\
\text { made themselves aware of } \\
\text { confirmation of purchase through } \\
\text { nav based tabs }\end{array}$ & $\begin{array}{c}\text { They easily selected payment option } \\
\text { and made themselves aware of the } \\
\text { confirmation of purchase through } \\
\text { nav based tabs. }\end{array}$ \\
\hline T7 & $\begin{array}{c}\text { Track order, Cancellation or } \\
\text { return process for placed } \\
\text { order. }\end{array}$ & $\begin{array}{l}\text { Required help to find the } \\
\text { navigation. }\end{array}$ & $\begin{array}{l}\text { Easily able to find and perform these } \\
\text { options as homepage contains true } \\
\text { navigation i.e. manage my orders. }\end{array}$ & Immediately performed all tasks. \\
\hline T8 & $\begin{array}{c}\text { Edit payment option after } \\
\text { order confirmation. }\end{array}$ & $\begin{array}{l}\text { Required help to understand the } \\
\text { task. }\end{array}$ & Required help to understand the task. & $\begin{array}{l}\text { Able to edit payment option after } \\
\text { product confirmation. }\end{array}$ \\
\hline T9 & Get anytime help required. & $\begin{array}{c}\text { Easily found an option such as } \\
\text { customer care number (displayed } \\
\text { on top) and get call facility for } \\
\text { help. }\end{array}$ & $\begin{array}{l}\text { Easily found an option such as } \\
\text { customer care number (displayed on } \\
\text { top) and get call facility for help. }\end{array}$ & $\begin{array}{l}\text { Easily found an option such as } \\
\text { customer care number (displayed on } \\
\text { top) and get call facility for help. }\end{array}$ \\
\hline T10 & $\begin{array}{c}\text { Writing review for purchased } \\
\text { product }\end{array}$ & $\begin{array}{l}\text { Required help to find write review } \\
\text { page. }\end{array}$ & Easily performed the task. & Immediately performed the task. \\
\hline
\end{tabular}


Table 16. Gap identified and required feature added

\begin{tabular}{|c|c|c|c|}
\hline Problem Theme & $\begin{array}{c}\text { Gap identified in GUI of Existing E-commerce } \\
\text { shopping site(List of Qualitative and quantitative } \\
\text { research entity) }\end{array}$ & Required Feature & Feature Description \\
\hline $\begin{array}{l}\text { Password-based } \\
\text { registration \& login }\end{array}$ & $\begin{array}{l}\text { Users show irritation to form and remember the } \\
\text { password for each shopping site. (WSS1, T6) }\end{array}$ & $\begin{array}{l}\text { Simple Login \& } \\
\text { registration process }\end{array}$ & $\begin{array}{c}\text { The user can enter mobile number or email id for } \\
\text { user id and request for verification code for a } \\
\text { password. }\end{array}$ \\
\hline $\begin{array}{l}\text { Missing features for } \\
\text { anytime help } \\
\text { required }\end{array}$ & $\begin{array}{c}\text { During registration and delivery check users are not } \\
\text { aware of a pin code. Beginners are not aware of online } \\
\text { shopping process stepwise. (WIS1, T3, T4, T6, T9). }\end{array}$ & $\begin{array}{c}\text { Link to } \\
\text { www.postindia.com, } \\
\text { Shopping Tour }\end{array}$ & $\begin{array}{l}\text { The website can provide resource link to get pin code } \\
\text { information. On home page compete shopping } \\
\text { process is listed stepwise. }\end{array}$ \\
\hline $\begin{array}{l}\text { Missing feature for } \\
\text { quick shopping and } \\
\text { real feel }\end{array}$ & $\begin{array}{l}\text { Users get confused with content of websites, missing } \\
\text { real shopping feel and minimize clicks (WII3, WSS2, } \\
\text { WNN1, WNN4, WIS6, T3, T5, T6, T7) }\end{array}$ & $\begin{array}{l}\text { Highlight Essential } \\
\text { Processes, Shopping } \\
\text { Assistant }\end{array}$ & $\begin{array}{c}\text { Essential processes can be the same color and } \\
\text { highlighted. Shopping assistant can provide a real } \\
\text { feel of shopping with minimum clicks that may lead } \\
\text { to quick shopping. }\end{array}$ \\
\hline $\begin{array}{l}\text { Confusion with } \\
\text { website wording }\end{array}$ & $\begin{array}{l}\text { Users find difficult to understand the meaning of words } \\
\text { used on the website. (WSR1, WII1, WSL3, WIA2, T3, } \\
\text { T5, T7, T8) }\end{array}$ & $\begin{array}{l}\text { Clear wordings, } \\
\text { number of standard } \\
\text { symbols }\end{array}$ & $\begin{array}{l}\text { All words should be meaningful and supported by } \\
\text { standard symbols (metaphors) so the user can } \\
\text { understand the clear meaning of written text. }\end{array}$ \\
\hline $\begin{array}{l}\text { Difficulty in content } \\
\text { Customization }\end{array}$ & $\begin{array}{l}\text { Users find difficult to use attribute-based filters to } \\
\text { customize the catalog. (WSR3, WNN1, WIS5, T4) }\end{array}$ & Need-based filter & $\begin{array}{l}\text { We should include generic types of filters along with } \\
\text { attribute based filters. }\end{array}$ \\
\hline Cluttered home page & $\begin{array}{l}\text { Users find difficult to understand home page because } \\
\text { of information overload in form of advertisements of } \\
\text { special offers, best deals of a day, etc. (WSR2, WSL1, } \\
\text { T3) }\end{array}$ & Clear home page & $\begin{array}{l}\text { The homepage should be clear and included with the } \\
\text { required information for all kind of personas. }\end{array}$ \\
\hline $\begin{array}{l}\text { Too much vertical } \\
\text { scrolling }\end{array}$ & $\begin{array}{l}\text { Users find difficulty in keeping patience and attention } \\
\text { while scrolling. The user may lose contents. That may } \\
\text { lead to improper learning of product. (WSR2, WSL2, } \\
\text { WSL3, WNN2, WIS3, T3, T4) }\end{array}$ & No vertical scrolling & $\begin{array}{c}\text { Sub content listing is done in nav tab frame (Screen } \\
\text { based controls). It reduces vertical scrolling and } \\
\text { enhances product learning }\end{array}$ \\
\hline $\begin{array}{c}\text { Difficulty to find } \\
\text { Contact information }\end{array}$ & $\begin{array}{l}\text { Users find difficult to get contact information. (WIS1, } \\
\text { WIA1, T9) }\end{array}$ & $\begin{array}{l}\text { Clear and easy to find } \\
\text { contact information }\end{array}$ & $\begin{array}{l}\text { There should be a toll-free number and contact email } \\
\text { Id at the top of the page. }\end{array}$ \\
\hline $\begin{array}{l}\text { Confusion in } \\
\text { accessing } \\
\text { Homepage from } \\
\text { interior page }\end{array}$ & $\begin{array}{l}\text { Users find difficult to move on to home page from } \\
\text { interior page because the indirect wording is used for } \\
\text { home page navigation. (WNN3, T3, T4, T5) }\end{array}$ & Accessible Homepage & Homepage link should be available on every page. \\
\hline $\begin{array}{l}\text { Missing edit } \\
\text { payment option, } \\
\text { appropriate } \\
\text { positioning of edit } \\
\text { option. }\end{array}$ & $\begin{array}{l}\text { Users could not find edit payment option after order } \\
\text { confirmation. Also, there is the inappropriate } \\
\text { positioning of edit option in the cart so beginners find } \\
\text { it difficult to find it. (WIA3, T5, T7) }\end{array}$ & $\begin{array}{c}\text { Edit card/cash on } \\
\text { delivery payment } \\
\text { method, Separate } \\
\text { column for edit cart } \\
\text { option }\end{array}$ & $\begin{array}{l}\text { Edit facilities after order confirmation to change } \\
\text { payment option. A separate column is added to edit } \\
\text { cart. }\end{array}$ \\
\hline False Navigation & $\begin{array}{l}\text { In some cases, the name of a link does not match with } \\
\text { the content and links are not located at the obvious } \\
\text { location. (WNN2, T8, T10) }\end{array}$ & $\begin{array}{l}\text { Reachable true } \\
\text { navigation }\end{array}$ & $\begin{array}{l}\text { Link name should match the contents of the } \\
\text { destination page. Also, links should be situated at an } \\
\text { obvious location on a page so users can recognize } \\
\text { them. A page should have navigation link to go to } \\
\text { other required pages on a site. }\end{array}$ \\
\hline $\begin{array}{l}\text { Missing go back } \\
\text { navigation }\end{array}$ & $\begin{array}{l}\text { Catalogue page is not reachable from the product page. } \\
\qquad(\text { WNN5, T5) }\end{array}$ & Go back navigation & $\begin{array}{l}\text { To select appropriate product from the catalog }(,) \\
\text { there is a need to move from the product page to } \\
\text { catalog page frequently. There should go back button } \\
\text { at appropriate places on the web page. }\end{array}$ \\
\hline $\begin{array}{l}\text { Missing facility of } \\
\text { accessible interactive } \\
\text { communication }\end{array}$ & $\begin{array}{l}\text { Accessible interactive communication such as getting a } \\
\text { call from an online company is missing. (WII } 4, \mathrm{~T} 9 \text { ) }\end{array}$ & $\begin{array}{l}\text { Direct facility to get a } \\
\text { call from the online } \\
\text { company. }\end{array}$ & $\begin{array}{l}\text { There should be an accessible facility to get a call } \\
\text { from the online company. }\end{array}$ \\
\hline $\begin{array}{l}\text { Missing date for last } \\
\text { updates on the } \\
\text { website. }\end{array}$ & $\begin{array}{l}\text { The user did not find last updated date for the website. } \\
\text { (WIS4, T4) }\end{array}$ & $\begin{array}{l}\text { Last updated date on } \\
\text { webpage (at least for } \\
\text { product catalog) }\end{array}$ & $\begin{array}{c}\text { There should be the date of last modification so that } \\
\text { users can keep track of when there is a change in } \\
\text { page contents. }\end{array}$ \\
\hline \multicolumn{4}{|c|}{ Additional Features were included in template Development } \\
\hline $\begin{array}{l}\text { Missing an } \\
\text { appropriate amount } \\
\text { of interactive feature }\end{array}$ & $\begin{array}{l}\text { Existing sites are less interactive. (WII2, T3 to T8, } \\
\text { T10) }\end{array}$ & $\begin{array}{l}\text { Popup window to } \\
\text { motivate user for } \\
\text { writing review, video } \\
\text { link for how to use } \\
\text { product }\end{array}$ & $\begin{array}{l}\text { With a help of pop-up windows, we can display a } \\
\text { notification for customer motivation and through } \\
\text { video links, we can show how to use products. }\end{array}$ \\
\hline $\begin{array}{l}\text { Missing feature for } \\
\text { error avoidance }\end{array}$ & $\begin{array}{c}\text { In existing website, error avoidance feature is less } \\
\text { addressed. (WIA2, T3 to T8) }\end{array}$ & $\begin{array}{l}\text { Text boxes with } \\
\text { instructions }\end{array}$ & $\begin{array}{l}\text { Text boxes are with proper instructions written in } \\
\text { placeholder or outside it. }\end{array}$ \\
\hline $\begin{array}{c}\text { Ambiguous error } \\
\text { messages }\end{array}$ & $\begin{array}{c}\text { On websites error messages are ambiguous. (WIA4, T3 } \\
\text { to T8) }\end{array}$ & Clear error messages & $\begin{array}{l}\text { The error produced during any process like a delivery } \\
\text { check, or any actions should be clear to understand. }\end{array}$ \\
\hline $\begin{array}{l}\text { Ambiguous feedback } \\
\text { for user action }\end{array}$ & $\begin{array}{l}\text { On websites some of the feedbacks for user action are } \\
\text { ambiguous. (WIS2, T3 to T8) }\end{array}$ & $\begin{array}{l}\text { Clear feedback for user } \\
\text { action }\end{array}$ & $\begin{array}{l}\text { Feedback to a user action such as get a call should be } \\
\text { a clear message that should intimate time duration to } \\
\text { get the call. }\end{array}$ \\
\hline
\end{tabular}

\section{ACKNOWLEDGMENT}

My special thanks to the research head Dr. G.T Thampi who have contributed towards the development of the paper.

\section{REFERENCES}

[1] R. Yazdanifard, A. Zargar, "Today's Need Of ECommerce Management To E-Skill Trainings", International Journal of E-Education, E-Business, E-
Management And E-Learning, Vol. 2, No. 1, February 2012.

[2] Kendall \& Kendall,"Human-Computer Interaction", Pearson Education.

[3] M. Patil, M. Rao, "Building efficiencies of e-commerce portal using intuitive GUI design in India: A Survey", IJIRST -International Journal for Innovative Research in Science \& Technology, ISSN (online): 2349-6010, Volume 2, Issue 07, PP.118-125, December 2015.

[4] C. Bataller, J. Harris, "Turning Cognitive Computing into Business Value. Today.” Accenture, May 21, 2015.

[5] "How to design mental models", 
http://Blog.Crazyegg.Com/2012/09/24/ [Accessed on Nov' 2015]

[6] Forrester Research, Inc. "Why Websites fail", The Forrester Report, 1998, pp.10

[7] J.Stone,"20 Do's And Don'ts of Effective Web Typography", http://webdesignledger.com/, 2009. [Accessed on November 2015]

[8] A. Kaur, D. Dani, "The Web Navigability Structure of EBanking in India", I.J. Information Technology and Computer Science, 2013, 05, 29-37, April 2013 DOI: 10.5815/ijitcs.2013.05.04

[9] U. Nwokedi, B. Onyimbo, B. Rad, "Usability and Security in User Interface Design: A Systematic Literature Review, I.J. Information Technology and Computer Science, 2016, 5, 72-80, May 2016, DOI: 0.5815/ijitcs.2016.05.08

[10] A. Nazir, A. Raana, N. Majeed," Highlighting the role of Requirement Engineering and User Experience Design in Product Development Life Cycle", IJMECS, vol.6, no.1, pp. 34-40, 2014.DOI: 10.5815/ijmecs.2014.01.04

[11] C. Eda, J. Afrancisco, M. Oz-Leiva, T. Luque, "Web Acceptance Model (WAM): Moderating Effects of User Experience", Information \& Management 2007 (44): 384396.

[12] D. Loeffler, A. Hess, A. Maier, J. Hurtienne , H. Schmitt, "Developing Intuitive User Interfaces by Integrating Users' Mental Models into Requirements Engineering”, The British Informatics Society Ltd., 2014.

[13] J. Tidwell, "The Case for HCI Design Patterns", http://Www.Mit.Edu/ / Patterns_Essay.Html, May 1999.

[14] D. Christopher, J. Lee, Y. Liu, E. Sallie, G. Becker, “An Introduction to Human Factors Engineering. Second Ed. Upper Saddle River", NJ: Pearson Prentice Hall, 2004, 185-193.

[15] J. Nielsen,"10 Usability Heuristics for User Interface Design", https://www.nngroup.com/articles/ten-usabilityheuristics/, January 1995, [Accessed on July 2016]

[16] K. Matz,"Donald-Normans-design-principles-forusability", http://architectingusability.com, June 2012. [Accessed on July 2016]

[17] T. Mandel, "The Elements of User Interface Design", John Wiley \& Sons, 1997.

[18] R. Saini, "Graphical User Interface Design Essentials \& Process", International Journal of Advanced Research in Computer Science and Software Engineering, September 2013, Volume 3, Issue 9.

[19] C. Storto, "A Distributed Cognition Framework to Compare E-Commerce Websites Using Data Envelopment Analysis", World Academy of Science, Engineering and Technology, 2009.

[20] M. Patil, M. Rao," Turning Cognitive computing into Design of Intuitive E-Commerce Portal: A Study", ELSEVIER, ScienceDirect, 7th International Conference on Communication, Computing and virtualization, Feb 2016, Procedia Computer Science, ISBN: 1877-0509, PP.139-143.

[21] M. Patil, M. Rao," Investigating Procedures for Intuitive GUI design of Indian E-commerce shopping sites", IOSR Journal of Computer Engineering (IOSR-JCE), Jul.-Aug. 2016, e-ISSN: 2278-0661,p-ISSN: 2278-8727, Volume 18, Issue 4, Ver. V , PP 159-169, DOI: 10.9790/0661180405159169.

[22] F. Egger, "Affective design of e-commerce user interfaces: How to maximise perceived trustworthiness", In Proc. Intl. Conf. Affective Human Factors Design, Singapore, London: Asean Academic Press, 2001

[23] J. Lewis, "IBM computer usability satisfaction questionnaires: psychometric evaluation and instructions for use", International Journal of Human-Computer Interaction, 1995, 7(1), pp.57-78.

[24] J. Nielsen, "Designing web usability: The practice of simplicity", San Francisco: New Riders Publishing, 1999.

[25] M. Roy, O. Dewit, B. Aubert, "The impact of interface usability on trust in web retailers", Internet Research, 2001, 11(5), pp.388-398.

[26] M. Zviran, C. Glezer, Avni, I., "User satisfaction from commercial websites: The effect of design and use", Information \& Management, 2006, 43(2), pp.157-178.

[27] P. Zhang, V. Small, G. Vondran, S. Barcellos, "A two factor theory for website design", 33rd Annual Hawaii International Conference on System Sciences. Maui, Hawaii, New Jersey: IEEE, 2000.

[28] R. Benbunan-Fich, "Using protocol analysis to evaluate the usability of a commercial website", Information \& Management, 2001, 39(2), pp.151-163.

[29] B. Shneiderman, "Designing the user interface-strategies for effective human-computer interaction", New Delhi: Pearson Education India, 1986.

[30] Z. Jiang, J. Chan, B. Tan, W. Chua, "Effects of interactivity on website involvement and purchase intention",Journal of the Association for Information Systems, 2010, 11(1), pp.34-59.

[31] G. Lohse, P. Spiller, "Internet retail store design: How the user interface influences traffic and sales",Journal of Computer-Mediated Communication, 1999, 5(2), pp.1-2.

[32] Rinder, J.M., "The Importance of Website Usability Testing", MSc. University of Oregon, 2012.

[33] Z. Huang, M. Benyoucef, "Usability and credibility of $e$ government websites", Government Information Quarterly, 2014, 31(4), pp.584-595.

[34] M. Patil, M. Rao, "Validating prototype of e-commerce shopping site in India", IEEE, 14th International Conference on Wireless and Optical Communications Networks (WOCN 2017), February 2017, ISBN: 978-15090-4883-0.

\section{Authors' Profiles}

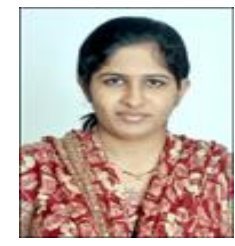

Megharani Patil has graduated from Mumbai University, in Computer Engineering in 2003. She completed her Master's Degree from Shivaji University in Academic Year 2010-11. She is pursuing Ph.D. from Mumbai University. Currently, she is working as an Assistant Professor at Thakur College of Engineering and Technology, Mumbai University. She has 13 years of teaching experience in the Institute. She has published more than 25 papers in international journals and conferences. She has also published $\mathrm{C}++$ and Java programming language books. Her area of interest is software engineering, user experience design, and artificial intelligence. Her interests also include web application development and mobile application development. She is a lifetime member of ISTE professional body.

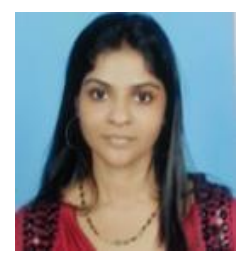

Dr. Madhuri Rao has Masters and a Ph.D. degree in computer engineering from Mumbai University. Currently, She is working as a Professor \& HOD in Information Technology department at TSEC, Bandra.She has more than 15 years of teaching experience. She has published 
more than 30 papers in international journals and conferences. Her area of interest is software engineering and data mining. She is also a research guide at Mumbai University.

How to cite this paper: Megharani T. Patil, Madhuri Y. Rao, "Building a Template for Intuitive Virtual E-Commerce Shopping Site in India", International Journal of Information Technology and Computer Science(IJITCS), Vol.10, No.2, pp.45-59, 2018. DOI: 10.5815/ijitcs.2018.02.05 